MaPan : Jurnal Matematika dan Pembelajaran

p-ISSN: 2354-6883 ; e-ISSN: 2581-172X

Volume 8, No 2, Dec 2020 (236-247)

DOI: https://doi.org/10.24252/mapan.2020v8n2a5

\title{
ANALYSIS OF HISTORICAL BUILDINGS NGAWEN TEMPLE IN MAGELANG
}

\author{
Rizki Sariningtias1), Reza Indriani2), Anisa Solihati ${ }^{3)}$, Alya Kamila4), Megita Dwi \\ Pamungkas ${ }^{5}$ \\ 1,2,3,4,5Program Studi Pendidikan Matematika, Universitas Tidar \\ 1,2,3,4,5]l. Kapten Suparman No.39, Magelang \\ Email: riskisariningtias@gmail.com¹), reza26indri@gmail.com²), \\ solihatianisa@gmail.com³), alyakamila512@gmail.com), megitadwip@untidar.ac.id5)
}

Received April 30, 2020; Revised May 26, 2020; Accepted December 09, 2020

\begin{abstract}
:
The analysis of historical buildings Ngawen Temple has a purpose of knowing the history of Ngawen Temple and knowing the approach to the Ngawen Temple's geometry. This research type is descriptive research with a qualitative approach. The subject of this research is the historical building of Ngawen Temple. The data collection techniques used in this research are interviews and documentation (observation) directly. The interview was done with the temple officers around the building, and the documentation was taken directly. The data analysis technique is done by analyzing the buildings related to the geometry, such as the building's shape on the Ngawen Temple. The results of this study were obtained; namely, Ngawen Temple set in Buddhism. The Ngawen Temple complex consists of 5 (five) temples that line the parallel from north to south. Temple building facing the east. From the south of Ngawen Temple I, II, III, IV, and V, each temple plans the square. One of Ngawen Temple's uniqueness is the existence of 4 lion statues in every corner of temple II and Candi IV. Another uniqueness is the temple's architecture, found in a lion's statue that supports the four sides of the temple building reconstructed from the five buildings. The lion statue's carved style resembles the lion symbol of Singapore's country and serves the rainwater that comes out through the statue's mouth. The Ngawen Temple's shape resembles the cuboid's geometry, the rectangular pyramidal frustum, and the rectangular pyramid.
\end{abstract}

Keywords: Ngawen Temple History, Building Analysis, Geometry Approach

\section{ANALISIS BANGUNAN BERSEJARAH CANDI NGAWEN DI MAGELANG}

\begin{abstract}
Abstrak:
Analisis bangunan bersejarah Candi Ngawen memiliki tujuan untuk mengetahui sejarah Candi Ngawen dan mengetahui pendekatan geometri Candi Ngawen. Jenis penelitian ini adalah penelitian deskriptif dengan pendekatan kualitatif. Subjek penelitian ini adalah bangunan bersejarah Candi Ngawen. Teknik pengumpulan data yang digunakan dalam penelitian ini adalah wawancara dan dokumentasi (observasi) secara langsung. Wawancara dilakukan dengan petugas kuil yang berada di sekitar
\end{abstract}

Copyright @ 2020, MaPan : Jurnal Matematika dan Pembelajaran 
gedung dan dokumentasi diambil langsung. Teknik analisis data dilakukan dengan menganalisis bangunan yang berkaitan dengan geometri seperti bentuk bangunan di Candi Ngawen. Hasil penelitian ini diperoleh, yaitu, Candi Ngawen berlatar agama Buddha. Kompleks Candi Ngawen terdiri dari 5 (lima) candi yang berjajar sejajar dari utara ke selatan. Bangunan kuil menghadap ke timur. Dari selatan Candi Ngawen I, II, III, IV, dan V dengan masing-masing pura untuk merencanakan alun-alun. Salah satu keunikan Candi Ngawen adalah keberadaan 4 patung singa di setiap sudut Candi II dan Candi IV. Keunikan lainnya adalah arsitektur candi, ditemukan di patung singa yang mendukung empat sisi bangunan candi yang direkonstruksi dari lima bangunan tersebut. Gaya ukiran patung singa menyerupai simbol singa Negara Singapura, dan menyajikan air hujan yang keluar melalui mulut patung. Bentuk Candi Ngawen menyerupai geometri cuboid, frustum piramida persegi panjang, dan piramida persegi panjang.

Kata Kunci: Sejarah Candi Ngawen, Analisis Bangunan, Pendekatan Geometri

How to Cite: Sariningtias, R., Indriani, R., Solihati, A., Kamila, A., \& Pamungkas, M. D. (2020). Analysis of Historical Buildings Ngawen Temple in Magelang. MaPan : Jurnal Matematika dan Pembelajaran, 236-247. https://doi.org/10.24252/mapan.2020v8n2a5.

\section{INTRODUCTION}

7 he science of mathematics is growing rapidly from time to time in the building construction that gave rise to beautiful buildings, including ancient historic buildings and modern buildings. The mathematics elements used are to determine the area, circumference, length, width, the height of a room in a building, the design of a building, the exact location, and calculations in the construction to create a sturdy building as expected. Buildings in mathematics are also applied in buildings construction such as cubes, beams, prisms, pyramids, cylinders, cones, and balls (Oktaviani, Nafisah, Apriliyani, Susanti, \& Pamungkas, 2019). These shapes are called geometry. Karen (1990) states that geometry typology helps understand historical texts about architecture that provide references about the geometry of floor plans, looks, and space. Typology is used as a tool for analyzing objects.

Geometry is a branch of mathematics that contains the properties of lines, angles, fields, and spaces (Fuadiah, 2009). Meanwhile, according to Danim (1995), geometry is one of the communication tools using appearance and structure regarding composition. The understanding of geometry that will be examined in the comparison of some of the architect's work is geometry, 
which refers to the presence of basic forms that contain geometric elements. Solid lines, fields, which can give us the ability to recognize shapes reflected in the appearance of a building, will be used as a reference in assessing the results of work in the study of geometry (Djadi, Minggi, Ja'faruddin, Zaki, \& Sidjara, 2017). Furthermore, according to Hafizin, Tendri, and Kusumawati (2018), geometry is the mathematics science that studies fields and space.

According to Keitel, Damerow, Bishop, and Gerdes (1989) states that, in the last ten years, there has been an increase in movement to make mathematics accessible to all students. Geometry research is one of them. Many researchers have carried out geometry research, one of which is Widyaningsih, Septena, and Pamungkas (2020), who suggested that the form of the Krapyak Stage resembles the geometric shapes, namely the cube. Also, Faizah, Andreyanto, Romadhoni, Rouf, and Pamungkas (2020) suggested that the basic shape of Fort Vredeburg is a rectangle, which at each corner is another regular congruent pentagonal form. Vredeburg Fort is a historical building from the Dutch colonial era in a square form where the four corners are made as a place of protection called Sloka or Bastion (Pradana, 2019). While from the front of this fortress has a geometrical element that is a beam. Furthermore, Khayat (2020) argues that the Fort named Van der Wijck is the only fortress in Indonesia that has an octagonal shape.

Mathematics and culture are indeed regarded as two things that have no relationship. Many people consider these two things as something impossible to put together. But without realizing it, ethnomathematics unites the two things. Ethnomathematics is an approach that links mathematics with culture. This association is expected to increase students' love for a culture to know the benefits of mathematics from a cultural perspective (Astuningtyas, Wulandari, \& Farahsanti, 2018). Meanwhile, according to Rachmawati (2012), ethnomathematics is a unique way used by a particular cultural group or community in mathematical activities. Furthermore, according to Albanese and Perales (2015), ethnomathematics is a research program focusing on the relationship between mathematics and culture. Whereas, D'Ambrosio (1985) argues that ethnomathematics is a field that gives the meaning that different ways of thinking can lead to various forms of mathematics. He got that in a bridge-making project by anthropologists, cultural historians, and mathematicians.

The role of ethnomathematics is very important as a means to motivate, stimulate students, overcome boredom, and give a new nuance to mathematics 
learning (Abi, 2017). Whereas Marsigit, Setiana, and Hardiarti (2018), argues that ethnomathematics functions to express the relationship between mathematics and culture. In line with Zhang and Zhang (2010) also said that ethnomathematics could be said as a process to look for the relationship between mathematics and culture. Research on ethnomathematics has also been carried out by many researchers, including Oktaviani, Nafisah, Apriliyani, Susanti, and Pamungkas (2019), that the Lawang SEWU building has geometric space structures, namely cubes, beams, pyramids, and octagonal prisms. Besides, Irsyad, Sujadi, and Setiana (2020) suggested the results of their research that there are mathematical elements (ethnomathematics) at Asu Temple, namely the concepts of rectangles, trapezoid, reflection, and geometry of space. Another researcher, Hardiarti (2017), also stated that through exploration, documentation, literature studies, and observations in the Muaro Jambi Temple environment, she concluded that there was the concept of a flat rectangular structure in several Muaro Jambi Temple structures. The structure is square, rectangular, longitudinal, trapezoidal, and rectangular irregular. Based on the background, the researcher took the theme of ethnomathematics, which is the geometrical approach to the historical building of the Ngawen Temple. This paper aims to find out the Ngawen Temple's history and know the Ngawen Temple's geometrical approach.

\section{METHODS}

This research is a descriptive study with a qualitative approach that aims to determine the Ngawen Temple's history and know the geometry approach of the Ngawen Temple. Descriptive research collects data based on factors that support the research object, then analyzing these factors to look for their role (Arikunto, 2010). Qualitative research deals with the ideas, perceptions, opinions, and beliefs of people to be studied. All of them cannot be measured by numbers. The theory used in this research is not forced to obtain a complete picture according to the views of humans studied (Basuki, 2006). Meanwhile, according to Cresswell (1998), what is meant by qualitative research is the type of research that produces findings that cannot be achieved (obtained) using statistical procedures or other ways of quantification (measurement). In qualitative methods, data processing is qualitative/inductive, and the results of the research put forward the meaning (Almansur \& Ghony, 2012; Sugiyono, 2015). 
Research on the history and approach to buildings in this geometry was carried out in the Ngawen Temple building, Ngawen Village, Muntilan District, Magelang Regency at coordinates 07 $36^{\prime} 14.7^{\prime \prime}$ LS and $110^{\circ} 16^{\prime} 21.4^{\prime \prime}$ East. The object of this research is the historical building of Ngawen Temple. Data collection techniques used in research are interviews and documentation (observation) directly. Interviews were carried out with temple guards in the building, and documentation was immediately taken. Documentation was taken in the form of a video interview about the history of the Ngawen Temple, and photographs of the Ngawen Temple cover the sides of the temple's feet, the temple's body, and the entire temple. The data analysis technique was carried out by analyzing buildings related to geometry, namely the shape of buildings in the Ngawen Temple.

\section{RESULTS AND DISCUSSION}

\section{Ngawen Temple History}

In the era of the Hindu-Buddhist kingdom, there were many kingdoms in Indonesia. These kingdoms provide various relics such as inscriptions, temples, books, and others. Most of these kingdoms are located on Java Island. Therefore, many royal relics on the island of Java. Among the relics are many famous relics such as Borobudur Temple, Prambanan Temple, Gedongsongo Temple, etc. Many small temple relics or nonintact temples are less well known by the wider public, such as Asu Temple, Wukir Temple, Lumbung Semi Temple, and Ngawen Temple.

Ngawen Temple is located in Ngawen Village, Muntilan District, Magelang Regency, Central Java. It consists of 5 temples, and we call it temple I, temple II, and so on. This temple is set in Buddhism. This evidence is from the Dhyani Buddha Ratnasambhawa statue's findings in Temple II and the statue of Dhyani Buddha Amithaba in Temple IV. Also, according to Irawan and Idris (2018), from an archaeological perspective, there are similarities in the architectural and ornamental components with three nearby Buddhist temples, namely Borobudur Temple, Pawon Temple, and Mendut Temple. Even Munandar in Irawan and Idris (2018) also hypothesizes that the four temples have a relationship. Despite the Buddhist background, the Ngawen Temple's shape is almost similar to the Hindu Temple building. This evidence is due to the building of a tapered temple. The building is also a large temple and small temple, which is characterized by a Hindu-patterned temple. But 
when observed, this temple has a stupa and a terrace that becomes a symbol in Buddhist temples. This temple was used as a place of worship.

Ngawen Temple has not been known for sure when and who built it. The reason is that the inscription that mentions it is invaluably not found. Until today, research is still conducted by ancient experts and historians. It is estimated that the temple's construction is a period with the construction of Borobudur Temple and Mount Wukir Temple in the 8th and 9th Centuries, during the ancient Mataram Kingdom. Based on the temple officer's information, an ancient scholar De Casparis argued that the archaeological complex was constructed by mutual assistance between the King of Pikatan Dyah Siladu of the Sanjaya Dynasty and King Samaratungga of the Syailendra Dynasty. The historical analysis is based on the central coral inscription in 824 M. In this inscription, King Samaratungga erected a holy building in a place that means bamboo forest. Ngawen Village was thought to be one of the villages overgrown by bamboo forest, and in the north of Ngawen Village, there is now a village called Gunungpring, where there is a hill that is still overgrown by bamboo groves.

The discovery of the Ngawen Temple began in the Dutch Colonial period, namely in 1874. After the discovery, then continued with various studies, and the restoration was only performed in 1925-1927. The restoration and reconstruction were not able to produce the whole temple. The reason is that many lost stones are made possible by natural disasters such as earthquakes or volcanic eruptions, which have swept away the rocks. From that restoration only produced the legs of the temple and the body of the temple II. It is estimated at the II temple is still less roof as high as 2-3 meters. To date, there are still efforts to reconstruct the temple by the institution that has its own, namely the Central Java Cultural Reserve Preservation Hall. The last time reconstruction was held in 2011-2012 at Temple IV.

\section{Geometric Approach Ngawen Temple}

The Ngawen Temple complex consists of 5 (five) temples lined parallel from north to south. The Temple building is facing the east. From the south of Ngawen Temple I, II, III, IV, and V, each temple plans the square. The II and IV temples have the same size and shape of construction. One of Ngawen Temple's uniqueness is the existence of 4 lion statues in every corner of temple II and Temple IV.

Another uniqueness is the temple's architecture, found in a lion's statue that supports the four sides of the temple building that was reconstructed from 
the five buildings. The lion statue's carved style resembles the lion symbol of Singapore's country and serves the rainwater that comes out through the statue's mouth. Ngawen Temple complex is approximately 900 square meters. Based on the reconstruction results that produce only the body of Temple II, temples other than Temple II are only the temple's foot in the form of cuboid and variant size.

Quoted from Sirumapea, Maesaroh, and Saputro (2020), in general, the temple consists of three essential parts, namely: (1) The foot of the temple, which is the part of the temple below. (2) The body of the temple, which is in the middle of the temple, is considered a Bhuwarloka. (3) The temple roof, located at the top of the temple, symbolizes the upper world or Swarloka.

The geometric analysis section of Ngawen Temple is as follows:

a) The Foot of the Temple

In Temple III, only the legs are left, as shown in figure 1. The remaining stones are not even enough to form a complete foot. The foot of Temple III is lying quite scattered like in the figure.

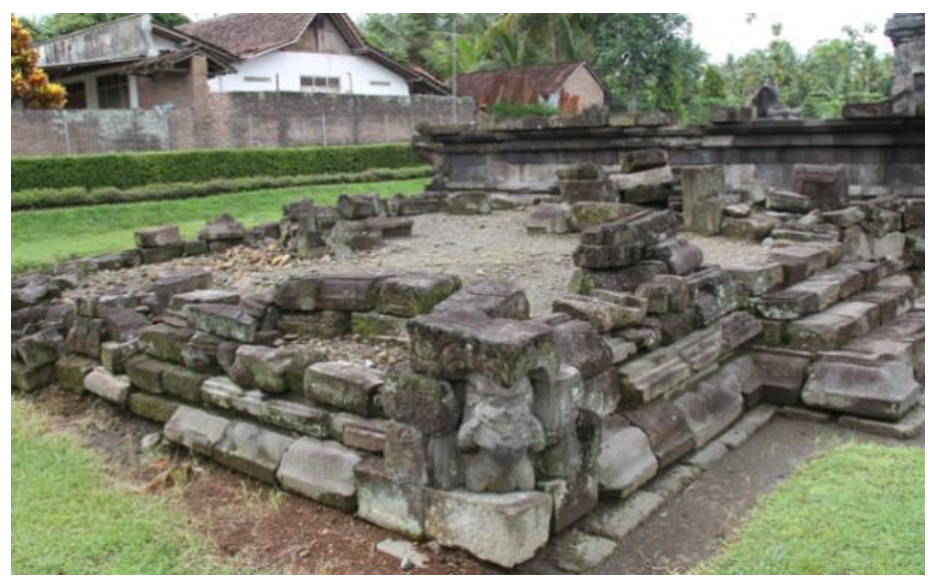

Figure 1. Temple's foot

As for Temple IV, there are quite many remaining stones to be sufficient for neater reconstruction. This condition is like in figure 2. The legs of Temple IV look neat and intact even though it is equipped with artificial stones. Temple IV is larger compared to Temple III. 


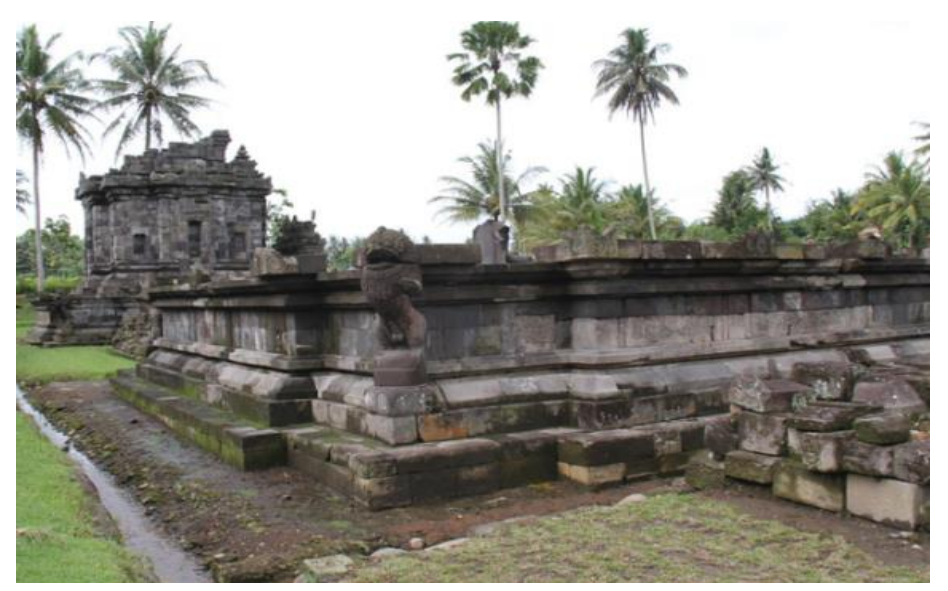

Figure 2. Temple's Foot IV

The foot of the temple is in the form of a beam. To make it easier to review geometrically, the authors attach sketches of temple legs from various angles. Figure 3 is a sketch of the temple's foot side view. Figure 4 sketch of the foot of the temple is a front view. Figure 5 shows the foot of the temple looks up.

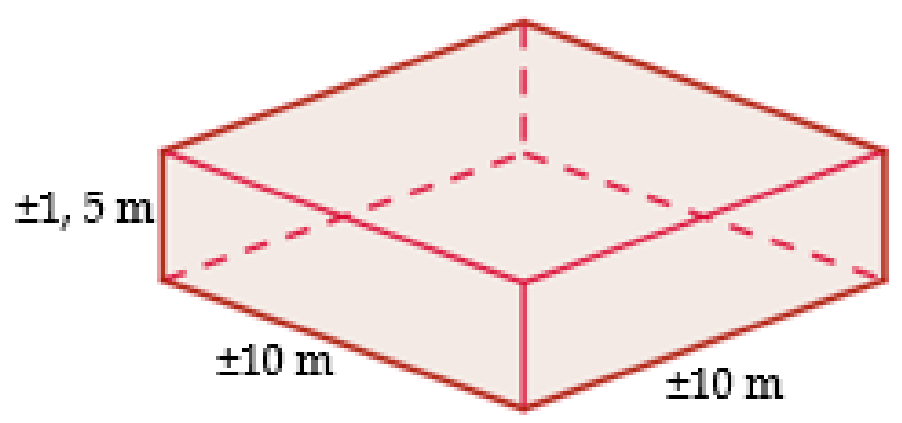

Figure 3. Temple's Foot Look Side

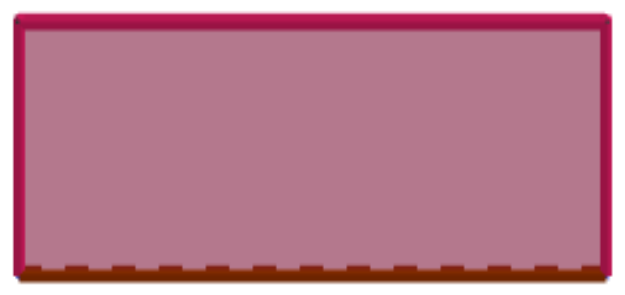

Figure 4. Temple's Foot Front View 


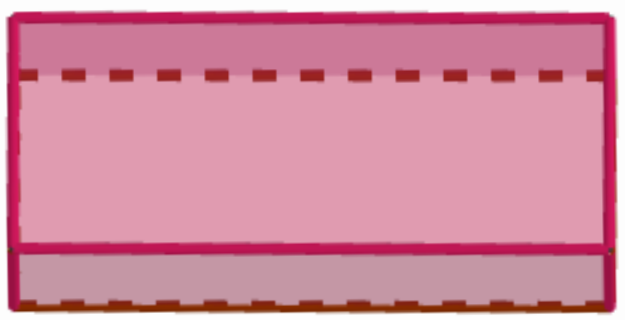

Figure 5. Temple's Foot Look Up

The size of Temple II is more or less like in the sketch, but for Temple II and Temple IV, the size is bigger. The foot of Temple II measuring $13.36 \mathrm{~m} \mathrm{x}$ $12.82 \mathrm{~m}$. The height of the temple is $2.32 \mathrm{~m}$, and the east view is $2.42 \mathrm{~m}$.

b) Body of the Temple

Figure 6 shows the Temple II side view. At the foot of Temple II, there is a hall surrounding the temple's body as wide as $1.10 \mathrm{~m}$. The photo also shows that there is a gate in front of the temple. For more details, you can see the sketch in figure 7 . The separate temple gate has a width of $4.9 \mathrm{~m}$, the entrance gate is $1.05 \mathrm{~m}$, and the height is $2.1 \mathrm{~m}$. The lower gate is in the form of blocks, while the upper part is in a quadrilateral pyramid.

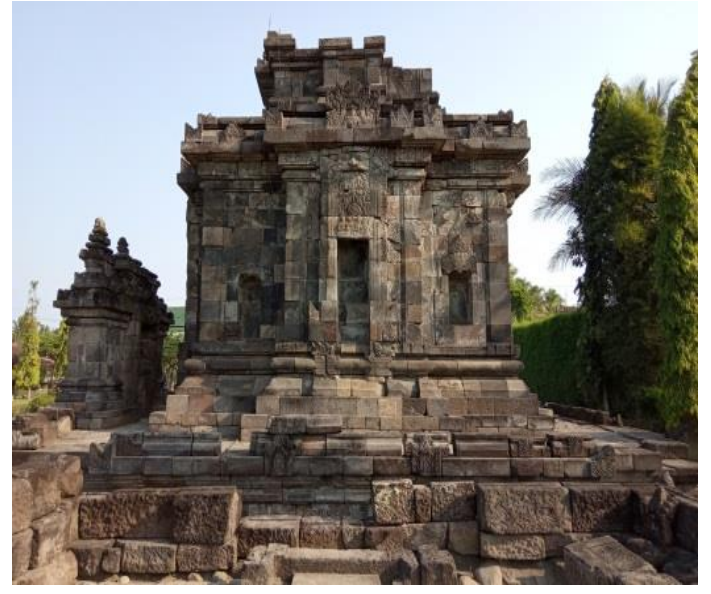

Figure 6. Temple II Side View

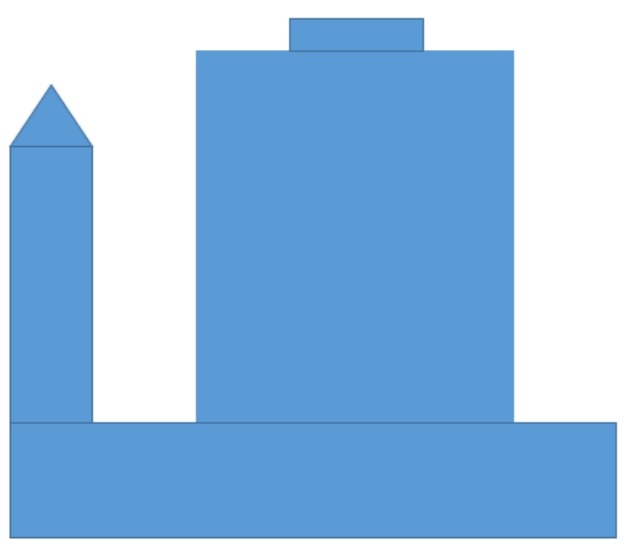

Figure 7. Sketch of Temple II Look Side

c) The Roof of the Temple

The look of Temple II in the front view can be seen in Figure 8, and the Sketch front view in figure 9. From the figure and the sketch, the temple's roof looks like a trapezoid in 2 dimensions. However, when viewed from the front and sides, this roof is in a rectangular pyramid. 


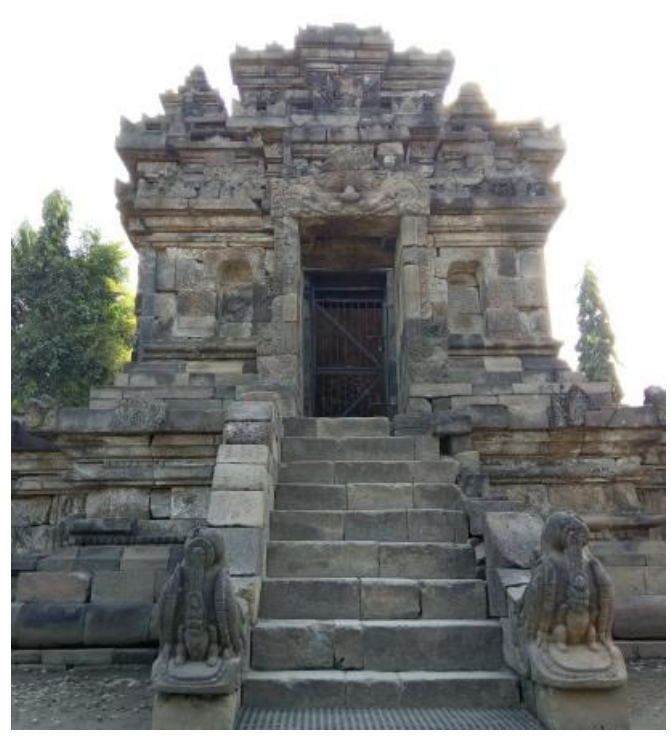

Figure 8. Temple II Front View

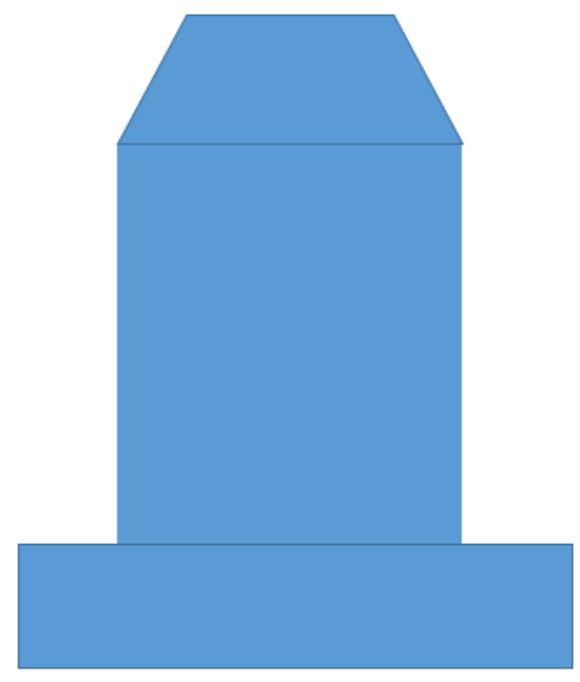

Figure 9. Sketch of Temple II Front View

\section{CONCLUSIONS}

Ngawen Temple complex is approximately 900 square meters. Based on the reconstruction results that produce only the body of Temple II, temples other than Temple II are only the temple's foot in the form of a beam and variant size. Likewise, in Temple II, because this temple is not found in the form of the Stupa, this temple is also the only variant of the arranged beam. The Footplan of Ngawen Temple II measuring $13.36 \mathrm{~m} \times 12.82 \mathrm{~m}$. The foot of the temple is $2.32 \mathrm{~m}$, and the East Side viewer $2.42 \mathrm{~m}$. Above the temple's foot is the lobby that surrounds the temple body as wide as $1.10 \mathrm{~m}$. While, the separate temple gate is the size, width $4.9 \mathrm{~m}$, the gate section $1.05 \mathrm{~m}$ and height $2.1 \mathrm{~m}$. Meanwhile, on the roof is the rectangular pyramidal frustum and the arch's upper part in a rectangular pyramid.

\section{ACKNOWLEDGMENT}

With the completion of this research article, the author thanked Allah SWT. Over the overflow of the gift, and it's her nose so that the authors can implement and complete the research articles. Both parents who have helped and supported in working on the research articles guards Ngawen Temple, who have assisted the research process, and the mathematics education lecturer who guided us in preparing research articles. 


\section{REFERENCES}

Abi, A. M. (2017). Integrasi Etnomatematika dalam kurikulum matematika sekolah. JPMI (Jurnal Pendidikan Matematika Indonesia), 1(1), 1-6. https:/ / doi.org/10.26737/jpmi.v1i1.75.

Albanese, V., \& Perales, F. J. (2015). Enculturation with etnomathematical micro project: from culture to mathematics. Journal of Mathematics $\mathcal{E}$ Culture, 9(1), 1-11. http:/ / dx.doi.org/10.30738/union.v8i1.6384.

Almansur, F., \& Ghony, D. (2012). Metodologi penelitian kualitatif. Yogyakarta: Ar-Ruzz Media.

Arikunto, S. (2010). Prosedur penelitian: suatu pendekatan praktik. Jakarta: Rineka Cipta.

Astuningtyas, E. L., Wulandari, A. A., \& Farahsanti, I. (2018). Etnomatematika dan pemecahan masalah kombinatorik. Jurnal Math Educator Nusantara, 3(2), 111-118. https:// doi.org/10.29407/ jmen.v3i2.907.

Basuki, S. (2006). Metode penelitian. Jakarta: Wedatama Widya Sastra.

Cresswell, J. (1998). Research design: qualitative $\mathcal{E}$ quantitative approach (Thousand O). CA: Sage Publications.

D'Ambrosio. (1985). Ethnomathematics and its place in the history and pedagogy of mathematics. For the Learning of Mathematics, 5(1), 44-48. Retrieved from https:// flm-journal.org/ Articles/72AAA4C74C1AA8F2 ADBC208D7E391C.

Danim, S. (1995). Media komunikasi pendidikan. Jakarta: Bumi Aksara.

Djadi, M., Minggi, I., Ja'faruddin, Zaki, A., \& Sidjara, S. (2017). Sumber belajar penunjang PLPG 2017 mata pelajaran paket keahlian matematika bab $x$ bangun datar. Jakarta: Kementerian Pendidikan dan Kebudayaan Direktorat Jenderal Guru dan Tenaga Kependidikan.

Faizah, R. S. N., Andreyanto, F., Romadhoni, V. D., Rouf, A., \& Pamungkas, M. D. (2020). Etnomatematika: analisis benteng vredeburg ditinjau dari segi geometri. Alauddin Journal of Mathematics Education, 2(1), 64-70. Retrieved from http://journal.uin-alauddin.ac.id/index.php/ajme/ article/view/13614.

Fuadiah, F. N. (2009). Pendekatan pendidikan matematika realistik Indonesia di SD Negeri 179 Palembang. Jurnal Pendidikan Matematika, 3(2), 73-84. https:// doi.org/10.22342/jpm.3.2.329.

Hafizin, M. A., Tendri, M., \& Kusumawati, N. I. (2018). Analisis kemampuan spasial siswa pada geometri kubus dan balok di Kelas IX SMP Negeri 03 Pulau Beringin. Jurnal Pendidikan Matematika, 3(2), 61-65. Retrieved from http:/ / ejournal.unitaspalembang.ac.id/index.php/nabla/article/ view/92.

Hardiarti, S. (2017). Etnomatematika: aplikasi bangun datar segiempat pada candi Muaro Jambi. Aksioma : Jurnal Matematika dan Pendidikan Matematika, 8(2), 99-109. https://doi.org/10.26877/aks.v8i2.1707. 
Irawan, A., \& Idris, M. (2018). Seni perhiasan dalam kebudayaan mataram kuno sebagai sumber pembelajaran sejarah (studi ikonografi relief Candi Borobudur). Kalpataru: Jurnal Sejarah Dan Pembelajaran Sejarah, 3(1), 11-24. http://dx.doi.org/10.31851/kalpataru.v3i1.1606.

Irsyad, M., Sujadi, A. A., \& Setiana, D. S. (2020). Eksplorasi ethnomatika pada candi Asu. UNION : Jurnal Pendidikan Matematika, 8(1), 11-19. https:// doi.org/10.30738/union.v8i1.7609.

Karen, K. (1990). Becoming attached: unfolding the mystery of the infant-mother bond and its impact on later life. New York: Warner Books.

Keitel, C., Damerow, P., Bishop, A., \& Gerdes, P. (1989). Mathematic; education and society (science and technology education document series No 35). Paris: UNESCO.

Khayat. (2020). Bangun datar pada benteng Van Der Wijck Gombong Jawa Tengah. Jurnal Pendidikan Matematika, 8(1), 121-129. https://doi.org/ 10.30738/union.v8i1.6384.

Marsigit, M., Setiana, D. S., \& Hardiarti, S. (2018). Pengembangan pembelajaran matematika berbasis etnomatematika. Prosiding Seminar Nasional Pendidikan Matematika Etnomatnesia. Yogyakarta.

Oktaviani, U., Nafisah, S., Apriliyani, M. N., Susanti, E., \& Pamungkas, M. D. (2019). Lawang Sewu dalam sudut pandang geometri. Jurnal Pendidikan Matematika, 2(1), 113-131. http://dx.doi.org/10.21043/jpm.v2i1.6348.

Pradana, W. (2019). Museum benteng Vredeburg Yogyakarta. Retrieved from https:/ / tribunnewswiki.com/2019/06/16museum-benteng-vredeburg yogyakarta.

Rachmawati, I. (2012). Eksplorasi etnomatematika masyarakat Sidoarjo. MATHEdunesa, 1(1). Retrieved from https://jurnalmahasiswa.unesa. ac.id/index.php/mathedunesa/article/view/249.

Sirumapea, A., Maesaroh, S., \& Saputro, K. E. (2020). Perancangan game petualangan mengenal candi-candi di Magelang. Academic Journal of Computer Science Research, 2(1), 8-14. Retrieved from https://journal. stmikglobal.ac.id/index.php/AJCSR/article/view/261.

Sugiyono. (2015). Metode Penelitian Pendidikan: Pendekatan kuantitatf, kualitatif, dan RED. Bandung: Alfabeta.

Widyaningsih, E., Septena, V. A., \& Pamungkas, M. D. (2020). Analisis bangunan bersejarah panggung krapyak terhadap geometri. UNION: Jurnal Ilmiah Pendidikan Matematika, 8(1), 111-119. http://dx.doi.org/ 10.30738/union.v8i1.6377.

Zhang, W. \& Zhang Q. (2010). Ethnomathematics and its integration within the mathematics curriculum. Journal of Mathematics Education, 3(1). 151-157. Retrieved from http://educationforatoz.com/images/_12_Weizhong Zhang_and_Qinqiong_Zhang.pdf. 